\section{AUTHORS:}

Nosiphiwe P. Ngqwala ${ }^{1}$

Petros Muchesa ${ }^{2}$ (DD

\section{AFFILIATIONS:}

Environmental Health and

Biotechnology Research Group,

Division of Pharmaceutical Chemistry,

Faculty of Pharmacy, Rhodes

University, Makhanda, South Africa

${ }^{2}$ Water and Health Research Centre,

Faculty of Health Sciences, University

of Johannesburg, Johannesburg,

South Africa

\section{CORRESPONDENCE TO:}

Nosiphiwe Ngqwala

EMAIL:

n.ngqwala@ru.ac.za

DATES:

Received: 31 Oct. 2018

Revised: 28 Feb. 2020

Accepted: 13 Mar. 2020

Published: 29 July 2020

\section{HOW TO CITE:}

Ngqwala NP, Muchesa P. Occurrence

of pharmaceuticals in aquatic

environments: A review and potential

impacts in South Africa. S Afr J

Sci. 2020:116(7/8), Art \#5730

7 pages. https://doi.org/10.17159/

sajs.2020/5730

\section{ARTICLE INCLUDES:}

囚 Peer review

$\square$ Supplementary material

\section{DATA AVAILABILITY:}

$\square$ Open data set

$\square$ All data included

$\square$ On request from author(s)

$\square$ Not available

凶 Not applicable

EDITOR:

Pascal Bessong iD

\section{KEYWORDS:}

water pollution, water systems,

impact of pharmaceuticals,

environmental pollution

FUNDING:

National Research Foundation (South Africa)

\title{
Occurrence of pharmaceuticals in aquatic environments: A review and potential impacts in South Africa
}

\begin{abstract}
The carbon footprint of pharmaceuticals through manufacturing, distribution, the incineration of unwanted pharmaceuticals as well as the packaging of pharmaceutical waste is an emerging and enormous challenge. Pharmaceuticals are major contributors to water pollution in aquatic environments that include surface water and groundwater. These pollutants arise not only from waste products but also from pharmaceutical products that have not been properly disposed of. The continuous exposure to unspecified sub-therapeutic doses of antibiotics presents risks to humans and other animals. Due to their extensive use and incomplete elimination, antibiotics have been detected in various environmental waters. The persistence of antibiotics in the environment and chronic exposure of organisms to these chemical stressors has also proven to have ecotoxicological effects. The prevailing emergence of antimicrobial resistance amongst bacteria is an area of primary concern, especially with regard to the release of antibiotics into the environment. Resistance is the acquired ability of bacterial populations to render an antibiotic ineffective as a result of a change in bacterial DNA which occurs when bacteria are subjected to an antibiotic concentration that will not kill them. A sub-lethal concentration possibly exerts a selective pressure that can result in the development of antimicrobial resistance in bacteria. It is clear that there is a need for extensive research to improve regulations and guidance on pharmaceutical waste management, pharmaceutical take-back programmes and consumer awareness.
\end{abstract}

\section{Significance:}

Pharmaceuticals are major contributors to water pollution in aquatic environments that include surface water and groundwater. This review examines the potential sources of pharmaceuticals in aquatic environments, their occurrence in South Africa, and public and environmental health implications posed by their presence. This information will provide a baseline for research and development to optimise water treatment technologies and to improve national, provincial, regional and municipal regulations and legislation.

\section{Introduction}

Pharmaceuticals are among the prime examples of contaminants that have recently been detected in water systems, with up to $90 \%$ of oral drugs that pass through the human body ending up in the water supply. ${ }^{1}$ These emerging pollutants, therefore, present a new global water quality challenge with potentially serious implications to human health and ecosystems. Some of the challenges include the development of antibiotic-resistant bacteria and genes $^{2}$, persistence of endocrine disrupting compounds in aquatic systems, and other deleterious ecotoxicological effects $^{3,4}$. The increased consumption, disposal and presence of human pharmaceuticals in the environment, particularly in aquatic systems, has raised concerns worldwide due to their continued introduction into the environment mainly via hospital effluents, agricultural activities and waste-water treatment plants (WWTP). Inadequate removal efficiencies of pharmaceuticals in WWTP leads to contamination of surface water, groundwater and treated drinking water., ${ }^{5,6}$ Therefore, legislative measures need to be in place to prevent and manage any possible risks that these compounds pose to aquatic systems. In places such as Australia, Canada, the USA and some European countries where preventative measures have been implemented, the regulations are stringent and mainly apply to controlled substances and cytotoxic drugs other than pharmaceuticals and still preclude the release in sewage. However, most low- and middle-income countries, including South Africa, do not have regulations pertaining to pharmaceutical traces as pollutants in aquatic systems. This absence has resulted in very little or no environmental monitoring of these chemical stressors. ${ }^{7}$

The presence of pharmaceutically active compounds at low concentrations in surface water, groundwater, seawater, sediments or drinking water has been reported worldwide for more than 50 years. ${ }^{8}$ The rapidly growing pharmaceutical industry has been pushed by the high consumption of pharmaceuticals, resulting in high frequency of detection of these contaminants in aquatic environments. ${ }^{9}$ Pharmaceuticals such as antibiotics, analgesics, antiinflammatories, hormones, non-steroidal anti-inflammatory drugs, beta-blockers, blood lipid regulators, and antiepileptics have been detected in aqueous environments in concentrations ranging from nanograms to micrograms

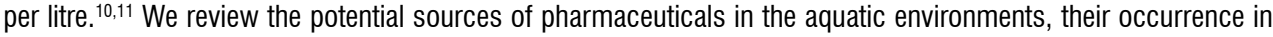
South Africa and public and environmental health implications posed by their presence.

\section{Pathways of pharmaceuticals in aquatic environment}

The number of pharmaceutical compounds that are prescribed for medical and veterinary use varies with region and country. Studies by Caldwell et al..$^{12}$ and Boxall et al. ${ }^{13}$ have reported 3500 and 4000 pharmaceutical compounds, respectively, that are consumed globally on a daily basis. Other studies in Europe and the USA have also reported a daily intake of 5000 and 10000 , respectively. ${ }^{14,15}$ However, the number of pharmaceuticals and their consumption in developing countries such as South Africa has not been quantified. The large consumption of pharmaceuticals by humans and other animals provides different pathways in which pharmaceuticals can enter aquatic environments. Pharmaceutical substances are biologically active and hydrophilic so that the human body can take them up (c) 2020. The Author(s). Published under a Creative Commons Attribution Licence. 
easily. In the body, they are persistent, to avoid degradation before they have a curing effect. Depending on the pharmacology of a medical substance, it can be excreted as a mixture of metabolites, as unchanged substance, or conjugated with an inactivating compound attached to the molecule. ${ }^{16,17}$ Generally, pharmaceutical compounds are metabolised by the body. Although some pharmaceuticals are completely degraded by the body, some are partially excreted through body wastes. These pharmaceuticals end up in the sewage system and eventually enter the environment through sewage leakages or discharge of waste water from sewage treatment plants which deposit into the aquatic systems (Figure 1)..$^{18,19}$

The main sources of pharmaceuticals are represented by improper disposal of medicines at domestic sites, hospital discharges, aquaculture facilities, animal farming activities, municipal and industrial WWTPs (Figure 1). ${ }^{20,21}$ Contamination of water sources by these pharmaceuticals can occur via various pathways, which include surface run-off or leaching of human and other animal waste, and wastewater effluent discharges. ${ }^{22,23}$ The conventional WWTPs consist of mechanical and chemical processes followed by biological treatment to remove, precipitate, and biodegrade the organic compounds based on their physicochemical characteristics. However, the majority of pharmaceuticals are not usually completely mineralised in conventional WWTPs equipped with primary and secondary processes. ${ }^{21,24}$ Although tertiary treatments using technologies such as reverse osmosis, ultrafiltration, nanofiltration, ozonation and photolysis are more efficient in the removal of pharmaceuticals ${ }^{21,25}$, their application in developing countries such as South Africa is relatively expensive. ${ }^{26}$ In the conventional treatment, they are either partially retained in the sludge, or metabolised to a more hydrophilic but still persistent form and, therefore, pass through the WWTP and enter surface water and groundwater. Their removal from waste water is variable and depends on the properties of the substance and process conditions such as sludge retention time, hydraulic retention time and temperature. ${ }^{27}$ Levels of many pharmaceutically active compounds barely reduce in waste-water treatment, and therefore are detected in treated effluents. In addition to agricultural activities, domestic and hospital waste water as main sources of pharmaceutical pollutants, and poor or no sanitation facilities in rural African communities can contribute to pharmaceutical contamination of water resources, as faecal matter is washed from the ground into the surface water during rainy seasons. ${ }^{28}$

\section{Pharmaceuticals in the aquatic environment of South Africa}

Pharmaceutical compounds are released mostly unchanged or as metabolites mostly conjugated to polar molecules which can be easily re-transformed to the original active compound before being diluted by the large volumes of water to sub-therapeutic concentration. ${ }^{28}$ Once in the aqueous environment, pharmaceuticals can be distributed to various facets of the environment. Most pharmaceutical products have low volatility and therefore spread throughout the environment mixed with water as aqueous solutions or suspensions; some may get adsorbed onto soil particles and enter a food chain. ${ }^{29}$ The presence of pharmaceuticals in aquatic environments has been well established in developed countries due to their potential environmental and health impacts. Identified pharmaceuticals belong to the following groups: antibiotics, lipid regulators, beta-blockers, steroids and related hormones, cancer drugs, diuretics, anti-epileptics, antidepressants, tranquillisers, nonsteroidal anti-inflammatory drugs, anxiolytics, proton pump inhibitors and analgesics. ${ }^{30}$ These pharmaceuticals have been identified from environmental samples, with most being commonly used for the treatment of conditions related to the central nervous, cardiovascular and digestive systems (Table 1). ${ }^{31,32}$ Despite their wide use, relatively few studies have been done in Africa, including South Africa, to investigate the behaviour and fate of these emerging pollutants in the aquatic environment. In this review, we discuss the pharmaceuticals commonly detected in South African waters: analgesics, anti-inflammatories, antibiotics and antiretrovirals.

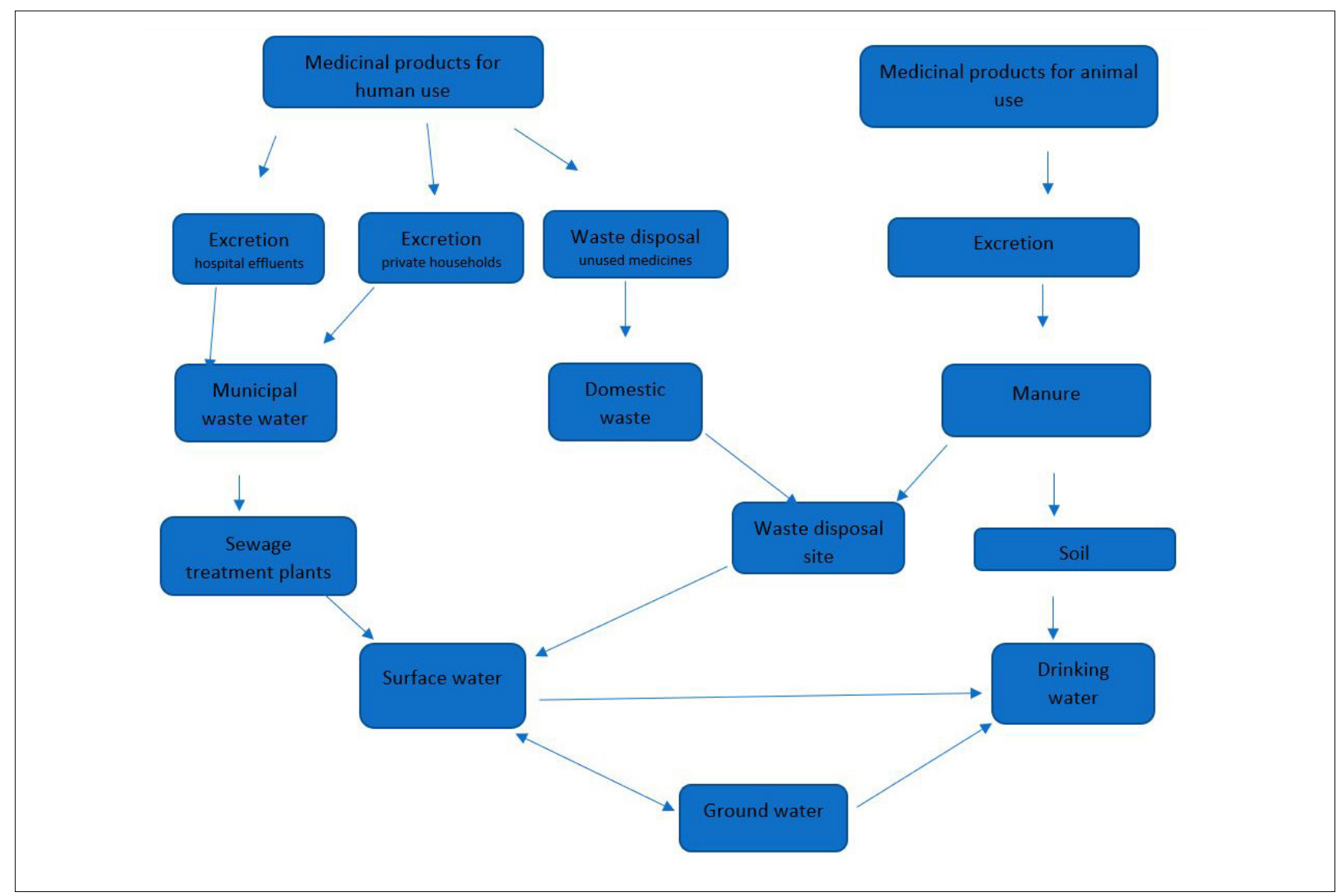

Figure 1: Sources and pathways by which pharmaceuticals may enter water resources. 
Table 1: $\quad$ Pharmaceuticals that have been found in aqueous ecosystems (adapted from Nikolaou et al..$^{31}$ and Gros et al. ${ }^{32}$ )

\begin{tabular}{|c|c|}
\hline Therapeutic groups & Pharmaceuticals \\
\hline Cancer drugs & Cyclophosphamide and ifosfamide \\
\hline Diuretics & Furosemide \\
\hline Anti-epileptics & Carbamazepine \\
\hline Antidepressants & $\begin{array}{l}\text { Mianserin, fluoxetine, citalopram, venlafaxine, } \\
\text { nordiazepam, oxazepam, 7-aminoflunitrazepam } \\
\text { and paroxetine }\end{array}$ \\
\hline Anxiolytics & Alprazolam, bromazepam, oxazepam \\
\hline Tranquillisers & Diazepam \\
\hline $\begin{array}{l}\text { Steroids and related } \\
\text { hormones }\end{array}$ & $\begin{array}{l}\text { 17-beta-oestradiol, oestrone, 17-alpha-ethinyloestradiol, } \\
\text { diethylstilboestrol and diethylstilboestrol acetate }\end{array}$ \\
\hline Beta-blockers & $\begin{array}{l}\text { Metoprolol, propranolol, nadolol, atenolol, sotalol } \\
\text { and betaxolol }\end{array}$ \\
\hline Antibiotics & $\begin{array}{l}\text { Erythromycin, ofloxacin, chlortetracyline, } \\
\text { oxytetracycline, streptomycin, ciprofloxacin, } \\
\text { trimethoprim, sulfamethoxazole, lincomycin, nalidixic } \\
\text { acid, amoxicillin and azithromycin }\end{array}$ \\
\hline Analgesics & $\begin{array}{l}\text { Aspirin, ibuprofen, paracetamol, metamizole, codeine, } \\
\text { indomethacin, acetaminophen, propyphenazone } \\
\text { and phenazone }\end{array}$ \\
\hline $\begin{array}{l}\text { Non-steroidal anti- } \\
\text { inflammatory drugs }\end{array}$ & Diclofenac, naproxen, ketoprofen and mefenamic acid \\
\hline Lipid regulators & $\begin{array}{l}\text { Bezafibrate, gemfibrozil, clofibric acid, mevastatin, } \\
\text { pravastatin and fenofibrate }\end{array}$ \\
\hline Anti-ulcer agents & Loratadine, famotidine and ranitidine \\
\hline Proton pump inhibitors & Lansoprazole \\
\hline
\end{tabular}

\section{Analgesics and anti-inflammatory drugs}

Analgesics are a class of pharmaceuticals that are used to relieve pain whereas anti-inflammatories are a class of drugs that are used to treat or reduce inflammation and swelling. Analgesics can have both antiinflammatory and antipyretic properties. ${ }^{33}$ The most commonly used analgesics and anti-inflammatories in South Africa include diclofenac, naproxen, ibuprofen, acetaminophen (paracetamol), aspirin and ketoprofen. ${ }^{34}$ Studies in South Africa have shown that ibuprofen is usually detected in aquatic environments in higher concentrations than other non-steroidal anti-inflammatory drugs. A study on the occurrence of selected pharmaceuticals in water and sediment of Umgeni River (KwaZulu-Natal, South Africa) by Matongo et al. ${ }^{35}$ reported concentrations of ibuprofen of up to $2.94 \mu \mathrm{g} / \mathrm{L}$ in effluent samples at the WWTP connected to the river. Their study further noted a higher concentration of ibuprofen $(12.94 \mu \mathrm{g} / \mathrm{L})$ in the effluent samples compared to influent samples, showing the ineffectiveness of the WWTP in removing ibuprofen. ${ }^{35}$ Therefore the receiving river could potentially be contaminated over time. Another study in the same province monitored naproxen, ibuprofen and diclofenac in a river and WWTP located around the city of Durban (KwaZulu-Natal, South Africa). In that study, maximum concentrations of $6.84 \mu \mathrm{g} / \mathrm{L}, 19.2 \mu \mathrm{g} / \mathrm{L}$ and $9.69 \mu \mathrm{g} / \mathrm{L}$ were reported for naproxen, ibuprofen and diclofenac, respectively. The corresponding maximum concentrations detected in WWTP effluent samples for naproxen, ibuprofen and diclofenac were $14.4 \mu \mathrm{g} / \mathrm{L}, 67.9 \mu \mathrm{g} / \mathrm{L}$ and $23.5 \mu \mathrm{g} / \mathrm{L}$, respectively. ${ }^{36} \mathrm{~A}$ maximum concentration of $221 \mu \mathrm{g} / \mathrm{L}$ was recorded in the same study from a WWTP influent sample. A study in the North West Province reported a maximum concentration of $13.7 \mu \mathrm{g} / \mathrm{L}$ for ibuprofen in effluent samples at a WWTP. ${ }^{37}$ In surface water, the highest concentration of ibuprofen $(62.0 \mu \mathrm{g} / \mathrm{L})$ was detected in KwaZulu-Natal at the point where a tributary, Msunduzi, joins the Umgeni River (Table 2). ${ }^{36}$

\section{Antibiotics}

Antibiotics are chemical entities constituting an integral part of modern medicine and are an essential line of defence against pathogenic bacteria and fungi by eradicating or inhibiting their growth. Approximately 200000 tonnes of antibiotics are produced every year, worldwide. . $^{38,39}$ Although antibiotics are useful, their overuse, inappropriate use and unregulated use have contributed to the presence of their metabolites and residues in the environment. Based on their biological and physicochemical properties, antibiotics can persist for extended periods of time in the environment, where they can contaminate water sources. ${ }^{40}$ There has been increasing concern over the past two decades about pollution of water sources by antibiotics, with several studies focusing on WWTP effluent discharges as potential hotspots of contamination. ${ }^{41,42} \mathrm{~A}$ huge proportion of antibiotics that are ingested end up in waste water and are amongst the most detected pharmaceuticals in WWTPs around the world. ${ }^{43}$ They are classified as recalcitrant bio-accumulative environmental pollutants, with the rate of degradation of most of these compounds such that it cannot offset their accumulation. ${ }^{44}$ Most antibiotics prescribed and dispensed cause side effects which differ in severity according to the agent used; however, in most cases, these side effects are outweighed by the therapeutic benefits and are therefore overlooked during chemotherapy. The major concern about the presence of antibiotics in the environment is the proliferation of antimicrobial resistance genes and antimicrobial resistance bacteria, which reduce the therapeutic potential against human and non-human animal bacterial pathogens. ${ }^{43}$

Several antibiotics have been reported in environmental waters due to their extensive use in humans and other animals to treat infections. The global increase in the use of these antibiotics has been observed in low- and middle-income countries, including South Africa, where there is a high incidence of diseases such as cholera, typhoid, meningitis, gonorrhoea, tuberculosis (TB) and malaria that are associated with drug-resistant pathogens. ${ }^{45,46}$ In addition, other factors such as the discharge of untreated waste, the low cost of individual antibiotics, the discharge through urine and faeces of animals and the lack of drug return programmes have been cited as contributors to the presence of antibiotics in most African waters. ${ }^{46}$ The occurrence of antibiotics in South African waters has been investigated in WWTPs as well as in surface waters. ${ }^{35,47,48,49}$ Among the investigated antibiotics in South African aquatic systems, a high concentration of sulfamethoxazole $(59.28 \mu \mathrm{g} / \mathrm{L})$ was detected at the influent of the WWTP of the Northern water works in Durban. ${ }^{35} \mathrm{~A}$ study by Agunbiade and Moodley ${ }^{50}$ detected ciprofloxacin at concentrations of $27 \mu \mathrm{g} / \mathrm{L}$ and $14 \mu \mathrm{g} / \mathrm{L}$ in the influent and effluent of a WWTP in KwaZulu-Natal. However, no ciprofloxacin has been reported in South African surface waters (Table 2). A more recent study to determine the concentrations of antibiotics and other pharmaceuticals at two hospital WWTPs in the North West Province reported a maximum of $45.38 \mu \mathrm{g} / \mathrm{L}$ and $3.22 \mu \mathrm{g} / \mathrm{L}$ in influent and effluent samples, respectively, for tetracycline. ${ }^{37}$ Other pharmaceuticals - namely azithromycin, ofloxacin, norfloxacin and erythromycin - have also been detected in WWTPs, but in lower concentrations $(<10 \mu \mathrm{g} / \mathrm{L}$ or $10 \mathrm{ng} / \mathrm{L}){ }^{35,48,49,51,52}$ To date, there are no studies that have reported the occurrence of antibiotics in potable drinking water in South Africa.

\section{Antiretroviral drugs}

Antiretroviral (ARV) treatment comprises a combination of nucleoside reverse transcriptase inhibitors, non-nucleoside reverse transcriptase inhibitors and protease inhibitors that act to inhibit multiple, viral targets and approved integrase inhibitors in patients with viral resistance, usually people with HIV. A combination of drugs is also used to prevent motherto-child transmission. ${ }^{52}$ In South Africa, at least 6.2 million people are HIV positive, according to statistics released in $2016 .{ }^{53}$ From that number, half of these individuals are enrolled for ARV therapy, with the number increasing every year. ${ }^{54} \mathrm{~A}$ study by Schoeman et al. ${ }^{55}$ estimated that around $162883 \mathrm{~kg}$ of ARV drugs could reach the aquatic systems in South Africa, based on high consumption figures of 2500000 and 2150880 people on ARV therapy in 2011 and 2012, respectively. ${ }^{56}$

The detection of ARV drugs in water resources of South Africa has been reported for the provinces of KwaZulu-Natal ${ }^{57,58}$, Gauteng ${ }^{59}$ and the Western Cape $^{60}$. The ARV drugs abacavir, atazanavir, darunavir, didanosine, efavirenz, emtricitabine, indinavir, lamivudine, lopinavir, maraviroc, nevirapine, raltegravir, ritonavir, saquinavir, tenofovir, zalcitabine and zidovudine have been reported in South African aquatic environments. Among ARV drugs, emtricitabine has been detected at the highest concentration of $172 \mu \mathrm{g} / \mathrm{L}$ in influent samples of a WWTP in the Western Cape. ${ }^{60}$ Low concentrations of up to $0.013 \mu \mathrm{g} / \mathrm{L}$ were reported for emtricitabine in a separate study in surface water samples. In South African aquatic environments, the most 
prevalent ARV drug detected has been efavirenz, which has been detected in Durban WWTP influent samples at high concentrations of up to $140 \mu \mathrm{g} / \mathrm{L}$ (Table 2). ${ }^{58}$ Low concentrations of efavirenz, ranging between $0.002 \mu \mathrm{g} / \mathrm{L}$

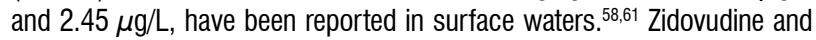
darunavir have also been detected at relatively high concentrations $(53 \mu \mathrm{g} / \mathrm{L}$ and $43 \mu \mathrm{g} / \mathrm{L}$, respectively) in the influent samples of WWTPs in KwaZuluNatal (Table 2). ${ }^{57}$

Table 2: Maximum concentrations for pharmaceuticals quantified in South African water bodies

\begin{tabular}{|c|c|c|c|c|}
\hline \multirow[t]{2}{*}{ Pharmaceuticals } & \multicolumn{3}{|c|}{$\begin{array}{l}\text { Maximum concentration } \\
(\mathrm{mg} / \mathrm{L})\end{array}$} & \multirow{2}{*}{ References } \\
\hline & $\begin{array}{l}\text { WWTP } \\
\text { Influent }\end{array}$ & $\begin{array}{l}\text { WWTP } \\
\text { Effluent }\end{array}$ & $\begin{array}{l}\text { Surface } \\
\text { water }\end{array}$ & \\
\hline
\end{tabular}

\begin{tabular}{|c|c|c|c|c|}
\hline \multicolumn{5}{|c|}{ Analgesics and anti-inflammatories } \\
\hline Ibuprofen & 221 & 67.9 & 62.0 & $\begin{array}{l}\text { Kanama et al. }{ }^{37} \text {; } \\
\text { Madikizela and } \\
\text { Chimuka }^{36}\end{array}$ \\
\hline Naproxen & 109.3 & 14.4 & 6.8 & $\begin{array}{l}\text { Madikizela and } \\
\text { Chimuka }^{36}\end{array}$ \\
\hline Diclofenac & 115.1 & 23.5 & 9.7 & $\begin{array}{l}\text { Madikizela and } \\
\text { Chimuka }^{36}\end{array}$ \\
\hline Fenoprofen & 80 & 47 & & Madikizela et al. ${ }^{34}$ \\
\hline \multicolumn{5}{|l|}{ Antibiotics } \\
\hline Sulfamethoxazole & 59.28 & 0.0803 & 6.01 & $\begin{array}{l}\text { Matongo et al. }{ }^{35} ; \\
\text { Nyamukamba et al. }{ }^{49}\end{array}$ \\
\hline Ciprofloxacin & 27 & 14 & & $\begin{array}{l}\text { Agunbiade and } \\
\text { Moodley }^{50}\end{array}$ \\
\hline Tetracycline & 45.38 & 3.22 & & Kanama et al. ${ }^{37}$ \\
\hline \multicolumn{5}{|c|}{ Antiretroviral drugs } \\
\hline Emtricitabine & 172 & 41.7 & 0.013 & $\begin{array}{l}\text { Mosekiemang et al.60; } \\
\text { Rimayi et al. }{ }^{61}\end{array}$ \\
\hline Efavirenz & 140 & 93.1 & 2.45 & Mtolo et al. ${ }^{58}$ \\
\hline Zidovudine & 53 & 0.5 & & Abafe et al. ${ }^{57}$ \\
\hline Darunavir & 43 & 17 & & Abafe et al. ${ }^{57}$ \\
\hline
\end{tabular}

WWTP, waste-water treatment plant

\section{Impacts of pharmaceuticals in aquatic systems}

Assessment of the environmental risk posed by pharmaceuticals and their metabolites has become a major focus in recent years because of their continuous introduction into aquatic systems. In the South African context, the fact that the country is classified as a water scarce country, makes the situation even more critical as there are relatively few water resources. Although pharmaceuticals may be present in aquatic environments in low concentrations, their extensive use, high reactivity with biological systems, continuous release and relatively low degradation makes them pseudo-persistent in aquatic environments. The potential effects to the environment and public health are chronic rather than acutely toxic, and depend on exposure, that is, bioavailability, susceptibility to the compound in question, and the degradability of the compound ${ }^{62}$ Globally, relatively few studies have focused on determining the toxicity of pharmaceuticals in the environment, putting humans and other animals at risk as there is a lack of information on the potential toxicity of these biologically active compounds. ${ }^{10}$

South Africa has been battling with epidemics of both TB and HIV/Aids over the last two decades. The country has the third worst TB epidemic worldwide (after China and India) and is among the six countries that account for $60 \%$ of the global TB burden. South Africa has the highest burden of the disease in Africa, with an estimated incidence of 454000 cases, at a rate of 834 cases per 100000 population as reported in $2015 .{ }^{63}$ Prevalence of HIV is the highest in the world, with $12.7 \%$ of the population in 2016 reported to be infected. ${ }^{63}$ In addition, South Africa reported the highest number of HIV-associated TB cases worldwide, with
$59.9 \%$ of TB patients co-infected with HIV in 2017. Furthermore, patients co-infected with TB and HIV have increased susceptibility to other infections such as Pneumocystis pneumonia. ${ }^{64}$ The prevalence of these two epidemics in South Africa means that tonnes of pharmaceuticals (ARV, antitubercular and antimicrobial drugs) are consumed to control the two epidemics. This presents a new problem concerning the presence and fate of these drugs in the aquatic environment. Pharmaceuticals can therefore pose potential environmental and public health issues that are of importance to South Africa.

\section{Environmental impacts}

Pharmaceuticals are designed to interfere with specific metabolic, enzymatic, or cell-signalling mechanisms at low concentrations through a specific mode of action in humans. The persistence of pharmaceuticals in the environment and chronic exposure to these chemical stressors can have ecotoxicological effects on non-target organisms. ${ }^{62,65}$ The nature of the aqueous environment, together with the physicochemical properties of the pharmaceuticals, also play an important role as they determine whether the pharmaceuticals will succumb to the processes (including the employed treatment) or persist in the environment. ${ }^{66}$ For example, fluoroquinolones, sulfonamides, trimethoprim and cephalosporins are resistant to microbial biodegradation and tend to persist in WWTP and other environmental compartments. ${ }^{67}$ Fluoroquinolones also have strong adsorptive properties and tend to accumulate on sediments and other organic matter thus elevating their persistence in environmental matrices ${ }^{65}$ In addition, the presence of antimicrobial compounds in the waste water at particular levels can reduce and/or inhibit the growth of sludge bacteria that are involved in biotransforming drugs and degrading organic matter. This inhibition can decrease the efficiency of the WWTP and may result in contamination of receiving water bodies. ${ }^{68}$

Toxicity studies of fish, daphnia and algae have been used to predict environmental concentrations and ecological risk of most pharmaceuticals. ${ }^{67,69}$ The biological activity of pharmaceuticals released in aquatic systems has been observed in nature and laboratory investigations have shown that they cause both acute and chronic effects. For example, the antibiotics clarithromycin sulfamethoxazole, ofloxacin, lincomycin, enrofloxacin and ciprofloxacin have been reported to be toxic to freshwater algae. ${ }^{20}$ Low concentrations (in nanograms/ litre) of the synthetic oestrogen 17-alpha-ethinyloestradiol often used in contraceptive pills have been shown to enlarge fish livers and affect the sexual characteristics of male fish in surface water. The antiinflammatory drug diclofenac also seems to be cause for concern for aquatic organisms..$^{70} \mathrm{~A}$ study done by Fent et al. ${ }^{71}$ reported that diclofenac was associated with the disappearance of the Orient whitebacked vulture in India and Pakistan. In mammals, diclofenac has been reported to affect the liver and kidneys. Furthermore, propranolol (a beta-blocker) detected in northeastern Spain was reported to have toxic effects on zooplankton and benthic organisms.

\section{Public health impacts}

Drinking water and consumption of aquatic organisms are two ways in which humans can be exposed to pharmaceuticals that pollute the aquatic environment. Therefore, possible risks of exposure for human health are a subject of concern, especially for the countries that use surface water as their main source of drinking water. Several quantitative pharmaceutical risk assessment studies on exposure to trace levels of pharmaceuticals in drinking water, conducted in different parts of the world, have shown very low risks to human health based on toxicological data. ${ }^{72,73}$ However, these studies do not rule out possible effects on human health as some studies are often been based on limited sets of monitoring data which do not consider long-term effects of exposure and have limited knowledge on the mixed effects of pharmaceuticals in drinking water consumed by humans. ${ }^{73}$ In addition, some studies focus on pharmaceutical concentrations in surface water only, and not drinking water, to assess human health risk, assuming that drinking water treatment plants do not remove any of the pharmaceuticals..$^{74,75}$

In addition to introducing toxins to drinking water, the development of resistance to antimicrobial compounds is another risk that pharmaceuticals 
in aquatic environments can pose to public health. The overuse and misuse of antibiotics may cause a risk to human health by promoting antibioticresistant bacteria and antibiotic resistance genes in aquatic environments. ${ }^{2,5}$ This occurs as a result of the high selective pressure imposed by antibiotics on bacteria. The bacterial community that can withstand this antimicrobial pressure will survive and multiply, leading to more resistant strains in the aquatic environments. ${ }^{76}$ The resistant genes can be horizontally transferred from animal to human pathogens and also across different classes of antibiotics used in veterinary and medical contexts, especially when the antibiotics have the same mechanism of action..$^{38}$ Horizontal gene transfer is a mechanism by which bacteria can disseminate novel traits, including acquired antimicrobial resistance. It is usually carried out by mobile DNA elements such as plasmids, transposons and integrons. ${ }^{77}$ When bacteria acquire resistance genes to protect them against various antibiotics, they are capable of employing several biochemical types of resistance mechanisms such as antibiotic inactivation, target modification, alteration in permeability and bypass metabolic pathway. ${ }^{78}$ Inadequate management of waste water may therefore release antibiotics, antibioticresistant bacteria and antibiotic resistance genes into the environment, thus presenting a potential environmental health risk. Antibiotic resistance is a major health concern; the presence of antibiotics in treated waste water is increasing and will lead to higher mortality and morbidity as untreatable infectious diseases increase. ${ }^{70}$

Antimicrobial resistance has become a great challenge in clinical therapy mainly because it compromises the effectiveness of antibiotics, resulting in therapeutic failure, elevated health costs, and increased morbidity and mortality rates. ${ }^{79}$ For example, pathogens such as multidrug resistant Klebsiella pnemoniae cannot be treated with any antibiotic currently on the market. ${ }^{76}$

\section{Research gaps and future perspectives in South Africa}

The presence, persistence and toxicity of pharmaceuticals in the aquatic environment is an important subject that needs to be extensively investigated to help prevent effects on the environment and human health. There is a lack of baseline studies in South Africa to counter any effects that can be caused by the presence of pharmaceuticals in South African water systems. South Africa has particular challenges, such as a high burden of HIV/Aids and TB, with resistant strains of TB prevalent in the population. This points to a high use of ARV drugs and antibiotics, resulting in relatively high concentrations being released into aquatic environments. Therefore, there is a need to quantify and determine their fate, and extrapolate their possible long-term effects on the environment and public health. There have been few studies conducted in South Africa on pharmaceutical drugs in water and their biodegradation profile, even though South Africa has an estimated 7.7 million people living with HIV, of which $62 \%$ of all people living with HIV in South Africa are on ARV treatment. Therefore, it is expected that the concentration of ARV drugs will be considerably high in waste water and surface water. This can be determined by comprehensive quantitative pharmaceutical risk assessments that are unique to the needs of South Africa. These studies will help to analyse different aspects of pharmaceutical exposure to the environment and humans, and the toxicity and associated health risks.

Removal of pharmaceuticals by WWTPs is important in reducing disposal to aquatic environments Currently, treatment processes in South Africa cannot remove pharmaceuticals completely, resulting in their discharge into water bodies. There is a need for research to determine how these sewage treatments are efficient in removing different types of pharmaceuticals. This can also be applied to drinking water plants that use potentially contaminated surface water as their source. This will help redesign treatment plants that can exhaustively remove pharmaceuticals that can be toxic or harmful to the environment and humans. Most quantitative pharmaceutical risk assessments have focused on urban areas, neglecting the rural populations that often utilise unpurified water for drinking. Therefore, studies in rural areas in South Africa will provide relevant information on the occurrence and fate of pharmaceuticals in the environment that can be compared to studies in urban areas. Not only do these pharmaceuticals negatively affect human life but they also affect aquatic life negatively. Several studies suggest diverse negative effects on aquatic life that are exposed to these trace amounts of pharmaceuticals in their habitats. South Africa is a semi-arid area, and pharmaceutical remains are especially harmful to aquatic life during drought, because the concentration automatically becomes higher due to low volumes of water.

Waste management is a pressing issue in South Africa, and improper dumping of dangerous health-care waste is a serious concern. The groups that are responsible for this misconception are nurses, pharmacists and other health-care professionals. It also places an unacceptably high financial and human resources burden on health authorities to manage the problem. Health-care waste entering the normal domestic waste stream will end up being disposed of in municipal landfill sites. When health-care waste is placed in landfills or buried, contamination of groundwater may occur and may result in the spread of Escherichia coli.

If landfills are insecure, expired drugs may come into contact with children and scavenging animals. Evidence suggests that the presence of antibiotics in waste water may be contributing to antibiotic resistance, and if these antibiotics are present in waste water for a longer period, they may cause genetic effects in humans and marine life. It is therefore essential that health-care facilities dispose of all waste in accordance with national, provincial, regional and municipal regulations and legislation. Hence, it is essential to raise public awareness and encourage consumers to adopt proper disposal practices for unwanted pharmaceuticals.

\section{Conclusion}

Pharmaceuticals are used in human and veterinary medicines, aquaculture, animal husbandry, and also in agriculture for the treatment of diseases. The uptake and excretion of these pharmaceuticals pose a risk for the contamination of aquatic systems. This is a good reason for intensive research into the fate of pharmaceuticals, which covers their detection, distribution, transformation, and impact on microorganisms in the surrounding environment, the development of resistance of microorganisms to pharmaceuticals, and the possible harmful effects on the treatment of animal and human bacterial disease. In addition, there should also be continued research and development to optimise water treatment technologies and to improve national, provincial, regional and municipal regulations and legislation. There is a need for cooperation of stakeholders, manufacturers, regulators, veterinarians, pharmacists and consumers to agree on ways to decrease the harmful levels of pharmaceuticals in the environment. It is also important that the pharmaceutical industry be responsible for the development and implementation of pollution control measures and monitoring thereof.

\section{Acknowledgements}

We acknowledge the National Research Foundation of South Africa and Rhodes University for their financial support.

\section{Authors' contributions}

N.P.N. conceptualised the review; both authors wrote the manuscript.

\section{References}

1. Pothitou P, Voutsa D. Endocrine disrupting compounds in municipal and industrial wastewater treatment plants in Northern Greece. Chemosphere. 2008;73(11):1716-1723. https://doi.org/10.1016/j.chemosphere.2008.09.037

2. Berendonk TU, Manaia CM, Merlin C, Fatta-Kassinos D, Cytryn E, Walsh F, et al. Tackling antibiotic resistance: The environmental framework. Nat Rev Microbiol. 2015;13(5):310-317. https://doi.org/10.1038/nrmicro3439

3. Saravanan M, Hur JH, Arul N, Ramesh M. Toxicological effects of clofibric acid and diclofenac on plasma thyroid hormones of an Indian major carp, Cirrhinus mrigala during short and long-term exposures. Environ Toxicol Pharmacol. 2014;38(3):948-958. https://doi.org/10.1016/j.etap.2014.10.013.

4. Peltzer PM, Lajmanovich RC, Attademo AM, Junges CM, Teglia CM, Martinuzzi $C$, et al. Ecotoxicity of veterinary enrofloxacin and ciprofloxacin antibiotics on anuran amphibian larvae. Environ Toxicol Pharmacol. 2017;51:114-123. https://doi.org/10.1016/j.etap.2017.01.021 
5. Houeto P, Carton A, Guerbet M, Mauclaire A, Gatignol C, Lechat P, et al. Assessment of the health risks related to the presence of drug residues in water for human consumption: Application to carbamazepine. Regul Toxicol Pharmacol. 2012;62(1):41-48. https://doi.org/10.1016/j.yrtph.2011.11.012

6. Moreno-González R, Rodriguez-Mozaz S, Gros M, Barceló D, León V. Seasonal distribution of pharmaceuticals in marine water and sediment from a Mediterranean coastal lagoon (SE Spain). Environ Res. 2015;138:326-344. https://doi.org/10.1016/j.envres.2015.02.016

7. He K, Soares A, Adejumo H, McDiarmid M, Squibb K, Blaney L. Detection of a wide variety of human and veterinary fluoroquinolone antibiotics in municipal wastewater and wastewater-impacted surface water. J Pharmaceut Biomed. 2015;106:136-143. https://doi.org/10.1016/j.jpba.2014.11.020

8. González Alonso S, Catalá M, Maroto R, Gil J, De Miguel Á, Valcárcel Y. Pollution by psychoactive pharmaceuticals in the Rivers of Madrid metropolitan area (Spain). Environ Int. 2010;36(2):195-201. https://doi. org/10.1016/j.envint.2009.11.004

9. Bayer A, Asner R, Schüssler W, Kopf W, Weiß K, Sengl M, et al. Behavior of sartans (antihypertensive drugs) in wastewater treatment plants, their occurrence and risk for the aquatic environment. Environ Sci Pollut Res. 2014;21(18):10830-10839. https://doi.org/10.1007/s11356-014-3060-z

10. Golet E, Alder A, Hartmann A, Ternes T, Giger W. Trace determination of fluoroquinolone antibacterial agents in urban wastewater by solid-phase extraction and liquid chromatography with fluorescence detection. Anal Chem. 2001;73(15):3632-3638. https://doi.org/10.1021/ac0015265

11. Yang $Y, O k Y, K i m ~ K$, Kwon $E$, Tsang $Y$ Occurrences and removal of pharmaceuticals and personal care products (PPCPs) in drinking water and water/sewage treatment plants: A review. Sci Total Environ. 2017;596:303320. https://doi.org/10.1016/j.scitotenv.2017.04.102

12. Caldwell DJ, Mastrocco F, Anderson PD, Länge R, Sumpter JP. Predicted-noeffect concentrations for the steroid estrogens estrone, 17 $\beta$-estradiol, estriol, and $17 \alpha$ - ethinylestradiol. Environ Toxicol Chem. 2012;31:1396-1406. https://doi.org/10.1002/etc. 1825

13. Boxall AB, Rudd MA, Brooks BW, Caldwell DJ, Choi K, Hickmann S, et al. Pharmaceuticals and personal care products in the environment: What are the big questions? Environ Health Perspect. 2012;120(9):1221-1229. https:// doi.org/10.1016/j.envint.2013.06.012

14. Dong Z, Senn DB, Moran RE, Shine JP. Prioritizing environmental risk of prescription pharmaceuticals. Regul Toxicol Pharmacol. 2013;65(1):60-67. https://doi.org/10.1016/j.yrtph.2012.07.003

15. Hughes SR, Kay P, Brown LE. Global synthesis and critical evaluation of pharmaceutical data sets collected from river systems. Environ Sci Technol. 2013;47(2):661-677. https://doi.org/10.1021/es3030148

16. Halling-Sørensen $B$, Nors Nielsen $S$, Lanzky P, Ingerslev F, Holten Lützhøft $H$, Jørgensen S. Occurrence, fate and effects of pharmaceutical substances in the environment - A review. Chemosphere. 1998;36(2):357-393. https://doi. org/10.1016/S0045-6535(97)00354-8

17. Clara M, Kreuzinger N, Strenn B, Gans 0 , Kroiss H. The solids retention time a suitable design parameter to evaluate the capacity of wastewater treatment plants to remove micropollutants. Water Res. 2005;39(1):97-106. https:// doi.org/10.1016/j.watres.2004.08.036

18. Madikizela L, Tavengwa N, Chimuka L. Status of pharmaceuticals in African water bodies: Occurrence, removal and analytical methods. J Environ Manag. 2017;193:211-220. https://doi.org/10.1016/j.jenvman.2017.02.022

19. Ayman Z, Işık M. Pharmaceutically active compounds in water, Aksaray, Turkey. CLEAN - Soil Air Water. 2015;43(10):1381-1388. https://doi. org/10.1002/clen.201300877

20. Klatte S, Schaefer HC, Hempel M. Pharmaceuticals in the environment - a short review on options to minimize the exposure of humans, animals and ecosystems. Sustain Chem Pharm. 2017;5:61-66. https://doi.org/10.1016/j. scp.2016.07.001

21. Yang $X$, Flowers RC, Weinberg HS, Singer PC. Occurrence and removal of pharmaceuticals and personal care products (PPCPs) in an advanced wastewater reclamation plant. Water Res. 2011;45(16):5218-5228. https:// doi.org/10.1016/j.scitotenv.2017.04.102

22. Zorita S, Mårtensson L, Mathiasson, L. Occurrence and removal of pharmaceuticals in a municipal sewage treatment system in the south of Sweden. Sci Total Environ. 2009;407:2760-2770. https://doi.org/10.1016/j. scitotenv.2008.12.030

23. Rodriguez-Mozaz S, Chamorro S, Marti E, Huerta B, Gros M, Sànchez-Melsió $A$, et al. Occurrence of antibiotics and antibiotic resistance genes in hospital and urban wastewaters and their impact on the receiving river. Water Res. 2015:69:234-242. https://doi.org/10.1016/j.watres.2014.11.021
24. Galán MJG, Díaz-Cruz MS, Barceló D. Removal of sulfonamide antibiotics upon conventional activated sludge and advanced membrane bioreactor treatment Anal Bioanal Chem. 2012;404(5):1505-1515. https://doi.org/10.1007/ s00216-012-6239-5

25. Peake BM, Braund R, Tong A, Tremblay LA. The life-cycle of pharmaceuticals in the environment. Cambridge: Elsevier; 2015.

26. Li $\mathrm{Y}$, Zhu G, Ng WJ, Tan SK. A review on removing pharmaceutical contaminants from wastewater by constructed wetlands: Design, performance and mechanism. Sci Total Environ. 2014;468:908-932. https:// doi.org/10.1016/j.scitotenv.2013.09.018

27. Vieno NM, Tuhkanen T, Kronberg L. Determination of pharmaceutical residues in fish bile by solid phase microextraction couple with liquid chromatography-tandem mass spectrometry (LC/MS/MS). Environ Sci Technol. 2005;39:8220-8226. https://doi.org/10.1021/es051124k

28. Segura PA, Takada H, Correa JA, El Saadi K, Koike T, Onwona-Agyeman S, et al. Global occurrence of anti-infectives in contaminated surface waters: Impact of income inequality between countries. Environ Int. 2015;80:89-97. https://doi.org/10.1016/j.envint.2015.04.001

29. Comerton AM, Andrews RC, Bagley DM. Practical overview of analytical methods for endocrine-disrupting compounds, pharmaceuticals and personal care products in water and wastewater. Philos $T$ R Soc $A$. 2009;367(1904):3923-3939. https://doi.org/10.1098/rsta.2009.0111

30. Ngumba E, Gachanja A, Tuhkanen T. Occurrence of selected antibiotics and antiretroviral drugs in Nairobi River Basin, Kenya. Sci Total Environ. 2016;539:206-213. https://doi.org/10.1016/j.scitotenv.2015.08.139

31. Nikolaou A, Meric S, Fatta D. Occurrence patterns of pharmaceuticals in water and wastewater environments. Anal Bioanal Chem. 2007;387(4):1225-1234. https://doi.org/10.1007/s00216-006-1035-8

32. Gros M, Petrović M, Barceló D. Development of a multi-residue analytical methodology based on liquid chromatography-tandem mass spectrometry (LC-MS/MS) for screening and trace level determination of pharmaceuticals in surface and wastewaters. Talanta. 2006;70(4):678-690. https://doi. org/10.1016/j.talanta.2006.05.024

33. Truter I. Prescribing patterns of anti-migraine medicines in South Africa using a claims database. Int J Clin Pharm. 2015;37(3):447-451. https://doi. org/10.1007/s11096-015-0089-0

34. Madikizela LM, Ncube S, Chimuka L. Analysis, occurrence and removal of pharmaceuticals in African water resources: A current status. J Environ Manage. 2020;253:109741.https://doi.org/10.1016/j.jenvman.2019.109741

35. Matongo S, Birungi G, Moodley B, Ndungu P. Occurrence of selected pharmaceuticals in water and sediment of Umgeni River, KwaZulu-Natal, South Africa. Environ Sci Pollut Res. 2015;22(13):10298-10308. https://doi. org/10.1007/s11356-015-4217-0

36. Madikizela LM, Chimuka L. Occurrence of naproxen, ibuprofen, and diclofenac residues in wastewater and river water of KwaZulu-Natal Province in South Africa. Environ Monit Assess. 2017;189(7):348. https://doi. org/10.1007/s10661-017-6069-1

37. Kanama KM, Daso AP, Mpenyana-Monyatsi L, Coetzee MA. Assessment of pharmaceuticals, personal care products, and hormones in wastewate treatment plants receiving inflows from health facilities in North West Province, South Africa. J Toxicol. 2018;2018, Art. \#3751930, 15 pages. https://doi.org/10.1155/2018/3751930

38. Davies J, Davies D. Origins and evolution of antibiotic resistance. Microbiol Mol Biol Rev. 2010;74(3):417-433. https://doi.org/10.1128/MMBR.00016-10

39. Rehman M, Rashid N, Ashfaq M, Saif A, Ahmad N, Han J. Global risk of pharmaceutical contamination from highly populated developing countries. Chemosphere. 2015;138:1045-1055. https://doi.org/10.1016/j. chemosphere.2013.02.036

40. Gothwal R, Shashidhar T. Antibiotic pollution in the environment: A review. CLEAN - Soil Air Water. 2014;43(4):479-489. https://doi.org/10.1002/clen.201300989

41. Costanzo S, Murby J, Bates J. Ecosystem response to antibiotics entering the aquatic environment. Mar Pollut Bull. 2005;51(1-4):218-223. https://doi. org/10.1016/j.marpolbul.2004.10.038

42. Leung $H$, Minh T, Murphy $M$, Lam J, So M, Martin M, et al. Distribution, fate and risk assessment of antibiotics in sewage treatment plants in Hong Kong, South China. Environ Int. 2012;42:1-9. https://doi.org/10.1016/j. envint.2011.03.004

43. Ncibi M, Sillanpää M. Optimized removal of antibiotic drugs from aqueous solutions using single, double and multi-walled carbon nanotubes. J Hazard Mater. 2015;298:102-110. https://doi.org/10.1016/j.jhazmat.2015.05.025 
44. Chen K, Zhou J. Occurrence and behavior of antibiotics in water and sediments from the Huangpu River, Shanghai, China. Chemosphere. 2014;95:604-612. https://doi.org/10.1016/j.chemosphere.2013.09.119

45. Ndihokubwayo JB, Yahaya AA, Desta AT, Ki-Zerbo G, Odei EA, Keita B, et al. Antimicrobial resistance in the African region: Issues, challenges and actions proposed. African Health Monitor. 2013;16:27-30.

46. Laxminarayan R, Duse A, Wattal C, Zaidi AK, Wertheim HF, Sumpradit N, et al. Antibiotic resistance - the need for global solutions. Lancet Infect Dis. 2013;13(12):1057-1098. https://doi.org/10.1016/s1473-3099(13)70318-9

47. Fekadu S, Alemayehu E, Dewil R, Van der Bruggen B. Pharmaceuticals in freshwater aquatic environments: A comparison of the African and European challenge. Sci Total Environ. 2019;654:324-337. https://doi.org/10.1016/j. scitotenv.2018.11.072

48. Faleye AC, Adegoke AA, Ramluckan K, Fick J, Bux F Stenström TA Concentration and reduction of antibiotic residues in selected wastewater treatment plants and receiving waterbodies in Durban, South Africa. Sci Total Environ. 2019;678:10-20. https://doi.org/10.1016/j.scitotenv.2019.04.410

49. Nyamukamba P, Moloto MJ, Tavengwa N, Ejidike IP. Evaluating physicochemical parameters, heavy metals, and antibiotics in the influents and final effluents of South African wastewater treatment plants. Pol J Environ Stud. 2019;28(3):1305-1312. https://doi.org/10.15244/pjoes/85122

50. Agunbiade FO, Moodley B. Occurrence and distribution pattern of acidic pharmaceuticals in surface water, wastewater, and sediment of the Msunduzi River, KwaZulu-Natal, South Africa. Environ Toxicol Chem. 2015;35:36-46. https://doi.org/10.1002/etc.3144

51. Swartz CD, Genthe B, Chamier J, Petrik LF, Tijani JO, Adeleye AP. Emerging contaminants in wastewater treated for direct potable re-use: The human health risk priorities in South Africa. WRC project no. K5/2369. Pretoria: Water Research Commission; 2016.

52. Shah AS, Stelzle D, Lee KK, Beck EJ, Alam S, Clifford S, et al. Global burden of atherosclerotic cardiovascular disease in people living with HIV: Systematic review and meta-analysis. Circulation. 2018;138(11):1100-1112. https:// doi.org/10.1161/circulationaha.117.033369

53. Statistics South Africa. Mid-year population estimates. Pretoria: Statistics South Africa; 2016. Available from: http://www.statssa.gov.za/publications/ P0302/P03022016.pdf

54. NDOH. National consolidated guidelines for the prevention of mother-to-child transmission of HIV and management of HIV in children, adolescents and adults [webpage on the Internet]. c2015 [cited 2020 Feb 28]. Available from: https://www.health-e.org.za/2015/

55. Schoeman C, Mashiane M, Dlamini M, Okonkwo OJ. Quantification of selected antiretroviral drugs in a wastewater treatment works in South Africa using GC-TOFMS. J Chromatogr Sep Tech. 2015;6(4), Art. \#272. https://doi. org/10.4172/2157-7064.1000272

56. World Health Organization. Global update on HIV treatment 2013: Results, impact and opportunities [webpage on the Internet]. c2013 [cited 2020 Feb 28]. Available from: www.who.int/hiv/pub/progressreports/update2013/en

57. Abafe OA, Späth J, Fick J, Jansson S, Buckley C, Stark A, et al. LC-MS/ MS determination of antiretroviral drugs in influents and effluents from wastewater treatment plants in KwaZulu-Natal, South Africa. Chemosphere. 2018;200:660-670. https://doi.org/10.1016/j.chemosphere.2018.02.105

58. Mtolo SP, Mahlambi PN, Madikizela LM. Synthesis and application of a molecularly imprinted polymer in selective solid-phase extraction of efavirenz from water. Water Sci Technol. 2019;79(2):356-365. https://doi. org/10.2166/wst.2019.054

59. Schoeman C, Dlamini M, Okonkwo OJ. The impact of a wastewater treatment works in Southern Gauteng. South Africa on efavirenz and nevirapine discharges into the aquatic environment. Emerg Contam. 2017;3(2):95-106. https://doi.org/10.1016/j.emcon.2017.09.001

60. Mosekiemang TT, Stander MA, De Villiers A. Simultaneous quantification of commonly prescribed antiretroviral drugs and their selected metabolites in aqueous environmental samples by direct injection and solid phase extraction liquid chromatography-tandem mass spectrometry. Chemosphere. 2019;220:983-992. https://doi.org/10.1016/j.chemosphere.2018.12.205

61. Rimayi C, Odusanya D, Weiss JM, De Boer J, Chimuka L. Contaminants of emerging concern in the Hartbeespoort Dam catchment and the uMngeni River estuary 2016 pollution incident, South Africa. Sci Total Environ. 2018:627:1008-1017. https://doi.org/10.1016/j.scitotenv.2018.01.263
62. Fabbri E. Pharmaceuticals in the environment: Expected and unexpected effects on aquatic fauna. Ann N Y Acad Sci. 2015;1340:20-28. https://doi. org/10.1111/nyas. 12605

63. World Health Organization (WHO). Global tuberculosis report 2016. Geneva: WHO; 2016. Available from: https://apps.who.int/iris/bitstream/hand le/10665/250441/9789241565394-eng.pdf;jsessionid=71484E5429BB1D 586F26C66F517D740F

64. World Health Organization (WHO). Global tuberculosis report 2018. Geneva: WHO; 2018. Available from: https://apps.who.int/iris/handle/10665/274453

65. MitaniK, Kataoka H. Determination of fluoroquinolones in environmental waters by in-tube solid-phase microextraction coupled with liquid chromatographytandem mass spectrometry. Anal Chim Acta. 2006;562(1):16-22. https:// doi.org/10.1016/j.aca.2006.01.053

66. Michael I, Rizzo L, McArdell C, Manaia C, Merlin C, Schwartz T, et al. Urban wastewater treatment plants as hotspots for the release of antibiotics in the environment: A review. Water Res. 2013;47(3):957-995. https://doi. org/10.1016/j.watres.2012.11.027

67. Ebele A, Abou-Elwafa Abdallah M, Harrad S. Pharmaceuticals and personal care products (PPCPs) in the freshwater aquatic environment. Emer Cont. 2017;3(1):1-16. https://doi.org/10.1016/j.emcon.2016.12.004

68. Magwira CA, Aneck-Hahn N, Taylor MB. Fate, occurrence and potential adverse effects of antimicrobials used for treatment of tuberculosis in the aquatic environment in South Africa. Environ Pollut. 2019;254, Art. \#112990. https://doi.org/10.1016/j.envpol.2019.112990

69. Godoy A, Kummrow F, Pamplin P. Occurrence, ecotoxicological effects and risk assessment of antihypertensive pharmaceutical residues in the aquatic environment - A review. Chemosphere. 2015;138:281-291. https://doi. org/10.1016/j.chemosphere.2015.06.024

70. Yao D, Xi X, Huang Y, Hu H, Hu Y, Wang Y, et al. A national survey of clinical pharmacy services in county hospitals in China. PLoS ONE. 2017;12(11), e0188354. https://doi.org/10.1371/journal.pone.0188354

71. Fent K, Weston A, Caminada D. Erratum to "Ecotoxicology of human pharmaceuticals". Aquat Toxicol. 2006;78(2):207. https://doi.org/10.1016/j. aquatox.2005.09.009

72. De Jesus Gaffney V, Almeida C, Rodrigues A, Ferreira E, Benoliel M, Cardoso $\mathrm{V}$. Occurrence of pharmaceuticals in a water supply system and related human health risk assessment. Water Res. 2015;72:199-208. https://doi. org/10.1016/j.watres.2014.10.027

73. Houtman C, Kroesbergen J, Lekkerkerker-Teunissen K, Van der Hoek J Human health risk assessment of the mixture of pharmaceuticals in Dutch drinking water and its sources based on frequent monitoring data. Sci Total Environ. 2014;496:54-62. https://doi.org/10.1016/j.scitotenv.2014.07.022

74. Cunningham V, Perino C, D'Aco V, Hartmann A, Bechter R. Human health risk assessment of carbamazepine in surface waters of North America and Europe. Regul Toxicol Pharmacol. 2010;56(3):343-351. https://doi. org/10.1016/j.yrtph.2009.10.006

75. Vulliet $E$, Cren-Olivé $C$. Screening of pharmaceuticals and hormones at the regional scale, in surface and groundwaters intended to human consumption. Environ Pollut. 2011;159(10):2929-2934. https://doi.org/10.1016/j. envpol.2011.04.033

76. Marti E, Variatza E, Luis Balcazar J, Balcazar JL. The role of aquatic ecosystems as reservoirs of antibiotic resistance. Trends Microbiol. 2014;22:36-41. https://doi.org/10.1016/j.tim.2013.11.001

77. Jain H, Mulay S, Mullany P. Persistence of endodontic infection and Enterococcus faecalis: Role of horizontal gene transfer. Gene Rep. 2016;5:112-116. https://doi.org/10.1016/j.genrep.2016.09.010

78. Giedraitienè A, Vitkauskienè A, Naginienè R, Pavilonis A. Antibiotic resistance mechanisms of clinically important bacteria. Medicina. 2011;47(3), Art \#19. https://doi.org/10.3390/medicina47030019

79. Munier A, De Lastours V, Barbier F, Chau F, Fantin B, Ruimy R. Comparative dynamics of the emergence of fluoroquinolone resistance in staphylococci from the nasal microbiota of patients treated with fluoroquinolones according to their environment. Int J Antimicrob Agents. 2015;46(6):653-659. https:// doi.org/10.1016/j.ijantimicag.2015.09.004 